\title{
Faktor-Faktor yang Memengaruhi Tingkat Literasi Keuangan Syariah pada Mahasiswa Muslim di Bogor
}

\section{Determinants of Islamic Financial Literacy Level of Muslim Students in Bogor}

\author{
Amelia Tri Puspita ${ }^{1}$, Deni Lubis ${ }^{2}$, Marhamah Muthohharoh ${ }^{3}$ \\ ${ }^{1}$ Fakultas Ekonomi dan Manajemen, Institut Pertanian Bogor, Jalan Raya Dramaga, Bogor 16680, \\ Indonesia, amelia.tri22@gmail.com \\ ${ }^{2}$ Fakultas Ekonomi dan Manajemen, Institut Pertanian Bogor, Jalan Raya Dramaga, Bogor 16680, \\ Indonesia,denilubis@gmail.com \\ ${ }^{3}$ Fakultas Ekonomi dan Manajemen, Institut Pertanian Bogor, Jalan Raya Dramaga, Bogor 16680, \\ Indonesia,muthohharohm@gmail.com
}

\begin{abstract}
The Indonesian Financial Services Authority (OJK) has targeted college students as one of the priority targets of their financial education programs in Indonesia. This research aimed to analyze the level of Islamic financial literacy of college students in Bogor; and analyze the factors that influence their level of Islamic financial literacy. The independent variable used in this study is the score of Islamic financial literacy. While gender, university, Grade Point Average (GPA), sources of information and religiosity are used as the dependent variables. The data analysis is conducted using the descriptive analysis and Structural Equation Modeling Partial Least Square (SEM-PLS). The estimation results showed that the level of Islamic financial literacy towards Muslim students in Bogor is 50.2\% and is classified as sufficient literate. The study found that gender and university have positively and significantly influenced the level of Islamic financial literacy of Muslim students in Bogor.
\end{abstract}

Keywords: Gender, Islamic financial literacy, Muslim students, Structural Equation Modeling, university.

\begin{abstract}
Abstrak. Mahasiswa merupakan salah satu target sasaran dari kegiatan edukasi keuangan oleh Otoritas Jasa Keuangan (OJK) dalam meningkatkan literasi dan inklusi keuangan. Subjek penelitian adalah mahasiswa Muslim di Bogor. Penelitian bertujuan untuk menganalisis tingkat literasi keuangan syariah mahasiswa dan menganalisis faktor-faktor yang memengaruhi literasi keuangan syariah mahasiswa. Faktor-faktor yang dianalisis yaitu jenis kelamin, universitas, Indeks Prestasi Semester (IPK), sumber informasi dan religiusitas. Metode analisis dalam penelitian ini adalah analisis deskriptif dan Structural Equation Modeling-Partial Least Square (SEM-PLS). Hasil penelitian menunjukkan bahwa tingkat literasi keuangan syariah mahasiswa Muslim di Bogor adalah sebesar 50.2\% dan tergolong sufficient literate. Faktor-faktor yang berpengaruh signifikan terhadap literasi keuangan syariah mahasiswa Muslim di Bogor adalah jenis kelamin dan universitas.
\end{abstract}

Kata kunci: Jenis kelamin, mahasiswa Muslim, Structural Equation Modeling, tingkat literasi keuangan syariah, universitas.

\section{PENDAHULUAN}

Sumber daya manusia yang berkualitas merupakan salah satu faktor yang memengaruhi dalam pembangunan ekonomi. Kualitas sumber daya manusia dalam konteks pembangunan ekonomi perlu terus ditingkatkan termasuk memperkuat kompetensinya, salah satunya terkait dengan literasi keuangan. Tujuan literasi keuangan adalah untuk meningkatkan kualitas seseorang dalam pengambilan keputusan keuangannya serta adanya perubahan sikap dan perilaku individu dalam pengelolaan keuangan menjadi lebih baik. Jika dikaitkan dengan literasi keuangan syariah, setiap individu harus memiliki pengetahuan dan wawasan serta pengelolaan dan penggunaan sumber dana sesuai dengan ajaran Islam. 
Pentingnya literasi keuangan bagi kalangan mahasiswa agar mahasiswa dapat mengelola keuangannya secara cerdas serta dapat meningkatkan pengetahuan dan wawasan dalam produk dan jasa keuangan. Sehingga, ketika mahasiswa tersebut sudah mulai melakukan investasi, tidak akan terjadi kesalahan dalam menentukan tempat untuk berinvestasi sehingga tidak akan terjadi penipuan dalam investasi yang tidak jelas.

Adams \& Rau (2011) menegaskan bahwa literasi keuangan mempunyai peran utama dalam persiapan masa pensiun. Boon et al. (2011) juga menemukan bahwa individu yang memiliki literasi keuangan lebih siap dalam melakukan perencanaan keuangan pribadinya. Dalam penelitian lain, Carpena et al. (2011) menemukan bahwa edukasi keuangan memengaruhi kesadaran dan sikap seseorang terhadap produk keuangan dan penggunaan berbagai instrumen perencanaan keuangan yang tersedia. Hasil Survei Nasional Literasi dan Inklusi Keuangan (SNLIK) yang dilakukan oleh Otoritas Jasa Keuangan (OJK) pada tahun 2013 dan 2016 mengenai tingkat literasi keuangan masyarakat Indonesia berdasarkan bank konvensional dan bank syariah dapat dilihat pada Gambar 1.

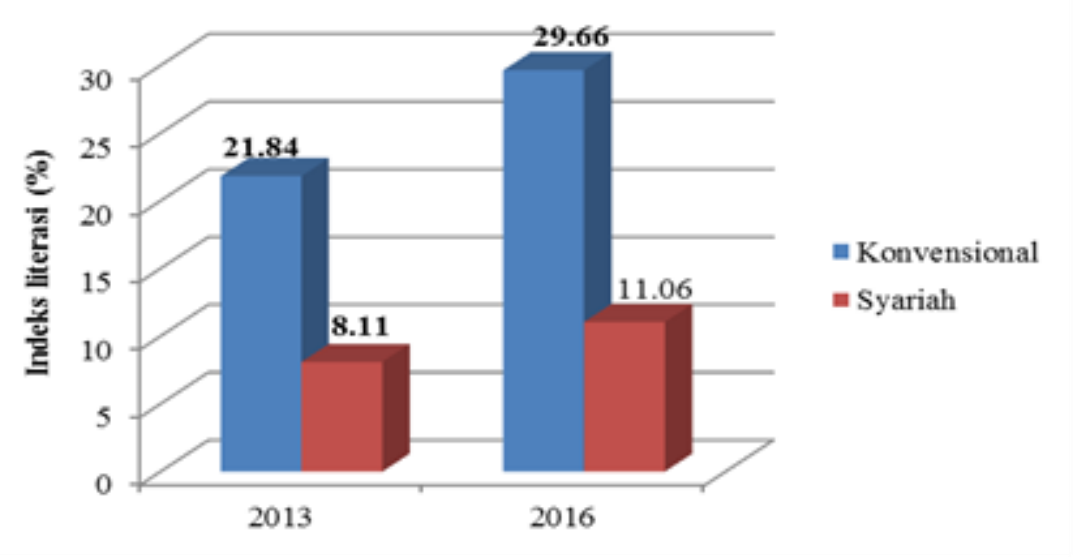

Sumber: Otoritas Jasa Keuangan, 2017

Gambar 1 Indeks literasi keuangan konvensional dan syariah Indonesia

Gambar 1 menunjukkan bahwa indeks literasi keuangan konvensional masyarakat Indonesia mengalami peningkatan dari tahun 2013 sampai tahun 2016 sebesar $21.84 \%$ menjadi $29.66 \%$. Penduduk yang termasuk kategori well literate sebanyak 22 orang dari setiap 100 penduduk pada tahun 2013, kemudian terjadi sedikit peningkatan pada tahun 2016 menjadi 30 orang. Artinya, hanya ada penambahan 8 orang pada tahun 2013 hingga 2016 yang termasuk kategori well literate. Jauh berbeda dengan hasil survei nasional literasi keuangan syariah. Masyarakat Indonesia mengalami peningkatan dari tahun 2013 sampai tahun 2016 sebesar 8.11\% menjadi 11.06\%. Penduduk yang termasuk kategori well literate sebanyak 8 orang dari setiap 100 penduduk pada tahun 2013 kemudian sedikit meningkat pada tahun 2016 menjadi 11 orang. Artinya, hanya ada penambahan 3 orang pada tahun 2013 hingga 2016 yang termasuk kategori well literate.

Peningkatan indeks literasi keuangan pada tahun 2016 masih jauh di bawah target yang dicanangkan pemerintah melalui Peraturan Presiden Republik Indonesia Nomor 82 tahun 2016 tentang Strategi Nasional Keuangan Inklusif (SNKI) pada akhir tahun 2019 yakni sebesar 75\%. Karena masih rendahnya literasi masyarakat, pemerintah mengeluarkan Peraturan Otoritas Jasa Keuangan 76/POJK07/2016 tentang peningkatan literasi dan inklusi keuangan di sektor jasa keuangan bagi konsumen/masyarakat. OJK mengeluarkan Strategi Nasional Literasi Keuangan Indonesia (SNLKI) untuk mengakselerasi dan mengoptimalkan pencapaian target indeks literasi dan inklusi keuangan. Visi SNLKI (Otoritas Jasa Keuangan, 2017) yaitu mewujudkan masyarakat Indonesia yang sejahtera secara keuangan dan well literate. Misi dari SNLKI yaitu melakukan edukasi dan pengembangan infrastruktur pengetahuan di bidang keuangan serta memperluas akses, ketersediaan produk dan layanan jasa keuangan yang sesuai kebutuhan dan kemampuan masyarakat. 
Strategi Nasional Literasi Keuangan Indonesia tahun 2013, Otoritas Jasa Keuangan mengklasifikasikan tingkat literasi keuangan masyarakat menjadi 4 tingkatan, yaitu: well literate, sufficient literate, less literate, dan not literate. Hasil survei nasional literasi keuangan syariah menunjukkan bahwa indeks literasi keuangan syariah masyarakat Indonesia pada tahun 2016 sebesar $11.06 \%$ yang mengindikasikan bahwa penduduk Indonesia masuk ke dalam kategori not literate. Untuk meningkatkan literasi masyarakat terhadap keuangan, Otoritas Jasa Keuangan menyelenggarakan berbagai program edukasi literasi keuangan yang di antaranya difokuskan kepada beberapa kelompok sasaran yaitu perempuan, pelajar/mahasiswa, UMKM, profesi, karyawan, pensiunan, disabilitas, TKI dan calon TKI, petani dan nelayan, dan masyarakat daerah terpencil.

Pelajar dan mahasiswa merupakan prioritas utama sasaran kegiatan edukasi keuangan. Mahasiswa sebagai agent of change dapat menjadi agen perubahan bagi masyarakat agar terhindar dari investasi yang merugikan, dengan cara menyebarkan informasi mengenai investasi sehat dan informasiinformasi lainnya terkait lembaga, produk dan jasa keuangan. Mahasiswa dianggap memiliki peran yang sangat penting karena salah satu keunggulan dari mahasiswa adalah cukup dekat dengan masyarakat (Otoritas Jasa Keuangan, 2017).

Jumlah penduduk Pulau Jawa menempati urutan pertama sebagai provinsi dengan jumlah penduduk terpadat se-Indonesia yaitu sebanyak $152,449,090$ jiwa. Di urutan kedua diikuti Pulau Sumatera dengan jumlah penduduk sebanyak 59,337,010 jiwa. Terakhir di urutan ketiga terdapat Pulau Sulawesi yaitu sebanyak 19,934,000 jiwa (BPS, 2020). Pulau Sulawesi menempati urutan ketiga dengan tingkat literasi keuangan syariah tertinggi se-Indonesia yaitu sebesar $6.55 \%$. Di urutan kedua terdapat Pulau Sumatera dengan tingkat literasi keuangan syariah tertinggi se-Indonesia yaitu sebesar 9.76\%. Terakhir di urutan pertama terdapat Pulau Jawa dengan tingkat literasi keuangan syariah tertinggi se-Indonesia yaitu sebesar 13.08\% (Otoritas Jasa Keuangan, 2017). Tabel 1 menunjukkan tingkat literasi keuangan syariah Pulau Jawa di Indonesia.

Tabel 1 Tingkat literasi keuangan syariah di Pulau Jawa tahun 2016

\begin{tabular}{cc}
\hline Wilayah & Indeks (\%) \\
\hline Jawa Timur & 29.4 \\
DKI Jakarta & 16.4 \\
Jawa Tengah & 11.2 \\
Daerah Istimewa Yogyakarta & 9.5 \\
Banten & 7.3 \\
Jawa Barat & 4.7 \\
\hline
\end{tabular}

Sumber: Otoritas Jasa Keuangan, 2017

Tabel 1 menunjukkan bahwa Jawa Barat memiliki indeks literasi keuangan yang paling rendah dibandingkan dengan provinsi lain di Pulau Jawa yaitu sebesar 4.7\%. Hasil tersebut menunjukkan bahwa tingkat kemampuan dan pengetahuan tentang keuangan syariah untuk masyarakat di Jawa Barat masih rendah. Pemilihan Bogor sebagai tempat penelitian karena Pemerintah Bogor memiliki program pancakarsa yang tertuang dalam visi dan misi Bupati dan Wakil Bupati untuk mewujudkan program minat baca di Bogor.

Pemerintah daerah Kabupaten Bogor melalui PKK Kabupaten Bogor dan PKK Kecamatan yang akan dilanjutkan melalui PKK Kelurahan dan Desa di tahun 2020 melaksanakan roadshow bunda literasi ke-10 titik kecamatan. Dalam kegiatan tersebut akan dikukuhkan bunda literasi desa dan kelurahan. Tujuannya untuk menjadi motivator untuk seluruh stakeholder yang ada di kecamatan untuk terus meningkatkan aktivitas gemar membaca (POSMI Bogor, 2020).

Oleh karena itu, penelitian ini bertujuan untuk mengetahui tingkat literasi keuangan syariah pada mahasiswa Muslim di Bogor. Tiga perguruan tinggi dengan jumlah mahasiswa terbanyak di Bogor adalah Institut Pertanian Bogor (IPB), Universitas Pakuan dan Universitas Juanda. IPB memiliki jumlah mahasiswa terbanyak pertama di Bogor yaitu sebanyak 31,221 orang, di posisi kedua 
ditempati oleh Universitas Pakuan sebanyak 19,067 mahasiswa, dan terakhir terdapat 6,044 mahasiswa pada Universitas Juanda.

\section{TINJAUAN PUSTAKA}

Organisation for Economic Co-operation and Development atau OECD (2006) mendefinisikan literasi keuangan sebagai pengetahuan dan pemahaman atas konsep dan risiko keuangan, berikut keterampilan, motivasi, serta keyakinan untuk menerapkan pengetahuan dan pemahaman yang dimilikinya tersebut dalam rangka membuat keputusan keuangan yang efektif, meningkatkan kesejahteraan keuangan (financial well being) individu dan masyarakat serta berpartisipasi dalam bidang ekonomi. Remund (2010) menyatakan bahwa literasi keuangan merupakan pengukuran terhadap pemahaman seseorang mengenai konsep keuangan, memiliki kemampuan dan keyakinan untuk mengatur keuangan pribadi melalui pengambilan keputusan jangka pendek yang tepat, perencanaan keuangan jangka panjang, serta memperhatikan kejadian dan kondisi ekonomi. Huston (2010) mengatakan literasi keuangan meliputi kesadaran dan pengetahuan akan instrumen keuangan dan aplikasinya di dalam bisnis dan kehidupannya.

Organisation for Economic Co-operation and Development atau OECD (2017) merumuskan bahwa literasi keuangan merupakan faktor fundamental bagi pertumbuhan ekonomi dan stabilitas keuangan. Menurut Lusardi \& Mitchell (2014), sudut pandang konsumen, literasi keuangan yang baik mengarah pada keputusan pengeluaran untuk mengutamakan kualitas. Ini akan menghasilkan persaingan industri yang sehat dan kompetisi terkait inovasi pada barang dan jasa yang ditawarkan kepada konsumen. Selain itu, dengan literasi keuangan yang baik bisa juga meminimalkan terjadinya keputusan yang salah pada masalah ekonomi dan keuangan yang muncul. Dari perspektif penyedia layanan keuangan, literasi keuangan yang baik akan memberikan informasi yang memadai tentang produk serta pemahaman risiko. Sementara itu, dari sudut pandang pemerintah, dengan kemampuan keuangan yang baik di masyarakat, pemerintah dapat memperoleh pendapatan pajak maksimum pembangunan infrastruktur dan fasilitas layanan publik.

Literasi keuangan terjadi ketika seorang individu memiliki seperangkat keterampilan dan kemampuan yang dapat memanfaatkan sumber daya yang ada untuk mencapai tujuan. Literasi keuangan membantu meningkatkan kualitas layanan keuangan, berkontribusi pada pertumbuhan ekonomi dan perkembangan suatu negara. Meningkatkan kompleksitas ekonomi, kebutuhan individu dan produk keuangan, individu harus memiliki kemampuan keuangan yang baik untuk mengelola keuangan pribadi.

Literasi keuangan syariah disebut juga dengan melek keuangan syariah yang berarti mengetahui dengan jelas produk dan jasa keuangan syariah, serta dapat membedakan antara bank konvensional dan bank syariah yang berpengaruh pada sikap seseorang dalam mengambil keputusan ekonomi sesuai dengan prinsip syariah. Menurut Rahim et al. (2016), literasi keuangan syariah merupakan kemampuan seseorang untuk menggunakan pengetahuan keuangan, kemampuan dan sikap untuk mengelola sumber keuangannya agar sesuai dengan prinsip syariah. Prinsip-prinsip keuangan syariah yaitu keyakinan pada tuntutan Ilahi, terhindar dari riba, tidak adanya investasi haram, tidak gharar (ketidakpastian), tidak maysir (judi/spekulasi), berbagi risiko dan pembiayaan didasarkan pada aset rill (Abdullah \& Razak, 2015).

Manajemen keuangan berkepentingan dengan bagaimana cara menciptakan dan menjaga nilai ekonomis atau kekayaan, sehingga akan berhadapan dengan keputusan keuangan (Keown et al., 2017). Horne dalam Kasmir (2010) mendefinisikan manajemen keuangan sebagai aktivitas yang berhubungan dengan perolehan, pendanaan, dan pengelolaan aktiva dengan beberapa tujuan menyeluruh. Menurut Brigham \& Houston (2006), manajemen keuangan adalah seni (art) dan ilmu (science) untuk me-manage uang, yang meliputi proses, institusi/lembaga, pasar, dan instrumen yang terlibat dengan masalah transfer uang antara individu, bisnis dan pemerintah. Adapun menurut Moeljadi (2006) manajemen keuangan dapat diartikan sebagai manajemen dana, baik yang berkaitan 
dengan pengalokasian dana dalam berbagai bentuk investasi secara efektif, pengumpulan dana untuk pembiayaan investasi secara efisien, dan pengelolaan aktiva dengan tujuan menyeluruh.

Lembaga keuangan adalah lembaga yang memberikan fasilitas dan produk di bidang keuangan serta memutar arus uang dalam perekonomian. Umumnya kegiatan operasional dari sebuah lembaga keuangan meliputi proses pengumpulan dana dari masyarakat dan menyalurkan dana kepada masyarakat yang membutuhkan. Lembaga keuangan menyalurkan kredit kepada nasabah atau menginvestasikan dananya dalam surat berharga di pasar keuangan. Lembaga keuangan juga menawarkan bermacam-macam jasa keuangan mulai dari perlindungan asuransi, menjual program pensiun sampai dengan penyimpanan barang-barang berharga dan penyediaan mekanisme untuk pembayaran dana dan transfer dana (Martono, 2004).

Penelitian Fadhly (2019) terkait literasi keuangan pada Mahasiswa S1 Institut Pertanian Bogor menggunakan metode analisis deskriptif dan Structural Equation Modeling (SEM) PLS menunjukkan hasil yang didapatkan yaitu rata-rata tingkat literasi keuangan mahasiswa sebesar $68.45 \%$ dan tergolong sufficient literate. Faktor-faktor yang berpengaruh terhadap literasi keuangan pada mahasiswa S1 Institut Pertanian Bogor adalah IPK dan fakultas.

\section{METODE}

Data yang digunakan terdiri atas data primer dan data sekunder. Data primer didapatkan dengan cara memberikan kuesioner kepada responden penelitian. Data sekunder digunakan untuk mendukung berbagai teori yang dibutuhkan dalam penelitian ini. Data sekunder diperoleh dengan cara studi pustaka dari referensi berupa buku, jurnal, skripsi, internet, serta arsip dari Otoritas Jasa Keuangan, yang berhubungan dengan penelitian.

Pemilihan lokasi penelitian di Institut Pertanian Bogor, Universitas Pakuan, dan Universitas Juanda karena ketiga universitas tersebut berada dalam peringkat 3 besar dengan universitas yang memiliki jumlah mahasiswa terbanyak di Bogor. Metode sampling dalam penelitian ini menggunakan metode non probability sampling dengan teknik purposive sampling, yaitu teknik sampling yang hanya sebagian populasi saja yang memiliki informasi tersebut. Jumlah sampel yang digunakan yaitu 150 responden.

Pemilihan jumlah sampel berdasarkan pendapat Bentler \& Chou (1987) yang menyatakan bahwa jumlah sampel tersebut sudah memenuhi persyaratan dalam penelitian yang menggunakan alat analisis Structural Equation Modeling (SEM) dengan menyarankan rasio minimal yaitu lima dikalikan indikator yang akan diamati sehingga data yang didapatkan mampu mencukupi untuk terdistribusi normal. Teknik pengambilan sampel dalam penelitian ini yaitu peneliti menyebarkan kuesioner sebanyak 180 orang di Institut Pertanian Bogor, Universitas Pakuan, dan Universitas Juanda. Kuesioner yang berhasil kembali sebanyak 160 kuesioner, tetapi sampel yang layak dianalisis hanya sebanyak 150 orang.

\section{Hasil Uji Validitas dan Reliabilitas}

Instrumen pada penelitian ini merupakan kuesioner yang diadaptasi dari kuesioner OECD/INFE Toolkit for Measuring Financial Literacy and Financial Inclusion tahun 2018. Namun, pertanyaanpertanyaan yang digunakan disesuaikan kembali dengan subjek penelitian yaitu mahasiswa. Penyesuaian dilakukan tanpa mengubah maksud dan tujuan pengukuran literasi keuangan syariah. Kuesioner terdiri dari 31 pertanyaan terkait 2 indikator religiusitas yaitu dimensi ritual dan dimensi sosial, dan 2 indikator literasi keuangan, yaitu sikap dan perilaku keuangan serta pengetahuan keuangan. 
Instrumen yang valid berarti instrumen tersebut dapat digunakan untuk mengukur apa yang seharusnya diukur (Sugiyono, 2013). Jika nilai r-hitung > r-tabel maka pertanyaan dinyatakan valid, dan sebaliknya jika nilai $r$-hitung $<$ r-tabel maka pertanyaan dinyatakan tidak valid. Pengujian validitas dengan jumlah responden sebanyak 30 orang dan tingkat signifikansi $1 \%$, nilai r-tabel sebesar 0.4487. Instrumen yang reliabel adalah instrumen yang bila digunakan beberapa kali untuk mengukur obyek yang sama, akan menghasilkan data yang sama (Sugiyono, 2013). Instrumen dinyatakan reliabel jika nilai alfa $>0.60$. Hasil pengujian validitas dan reliabilitas disajikan pada Tabel 2.

Tabel 2 Hasil uji validitas dan reliabilitas kuesioner

\begin{tabular}{llccc}
\hline & Indikator & $\begin{array}{c}\text { Jumlah butir } \\
\text { pertanyaan }\end{array}$ & $\begin{array}{c}\text { Jumlah } \\
\text { pertanyaan } \\
\text { valid }\end{array}$ & $\begin{array}{c}\text { Nilai Cronbach's } \\
\text { alpha }\end{array}$ \\
\hline Religiusitas & Dimensi Ritual & 6 & 6 & 0.793 \\
& Dimensi Sosial & 4 & 4 & 0.736 \\
\hline Literasi & Sikap dan Perilaku & 12 & 12 & 0.773 \\
Keuangan & Keuangan & 9 & 9 & 0.744 \\
& Pengetahuan Keuangan & & & \\
\hline
\end{tabular}

Sumber: Data diolah, 2020

Berdasarkan hasil uji validitas dan reliabilitas pada Tabel 2 menunjukkan seluruh pertanyaan telah memenuhi kriteria validitas dan reliabilitas sehingga instrumen penelitian dinyatakan valid dan reliabel.

\section{Analisis Deskriptif}

Analisis deskriptif bertujuan untuk membuat gambaran secara sistematis data yang akurat mengenai fakta-fakta serta hubungan antarfenomena yang diselidiki atau diteliti (Riduwan, 2010). Analisis deskriptif juga digunakan untuk menjelaskan data yang didapat berdasarkan karakteristik data hasil dari penelitian. Data hasil penelitian dideskripsikan dalam bentuk tabel.

Kategori tingkat literasi keuangan menurut Otoritas Jasa Keuangan (2016) dibedakan menjadi empat kategori yaitu well literate, sufficient literate, less literate, dan not literate. Pembobotan setiap kategori secara proporsional terbagi sebesar 25\%. Penentuan kategori ditentukan berdasarkan persentase jawaban benar dari pengisian kuesioner, yaitu total jawaban benar dibagi dengan total skor dan kemudian dipersentasekan.

Tabel 3 Kategori tingkat literasi keuangan

\begin{tabular}{cc}
\hline Kategori Literasi Keuangan & Persentase \\
\hline Well Literate & $76-100$ \\
Sufficient Literate & $51-75$ \\
Less Literate & $26-50$ \\
Not Literate & $0-25$ \\
\hline
\end{tabular}

Sumber: Otoritas Jasa Keuangan, 2016

\section{Analisis Partial Least Square-Structural Equation Model (PLS-SEM)}

SEM merupakan analisis yang tepat digunakan untuk analisis multivariate dalam penelitian sosial selain keuangan atau variabel yang digunakan menggunakan skala nominal/rasio, karena dalam beberapa kasus, penelitian harus menggunakan variabel laten (variabel yang tidak dapat diukur secara langsung). Misal kecerdasan, kepuasan konsumen, motivasi, dan komitmen. Variabel tersebut tidak dapat diukur secara langsung sehingga peneliti harus menggunakan beberapa indikator atau pertanyaan kuesioner. 
Berbeda dengan variabel yang terukur langsung seperti laba bersih, gaji, dll. Jika digunakan analisis regresi, maka setiap variabel tersebut diasumsikan dapat diukur secara langsung sehingga dapat menggunakan skor rata-rata atau total dari item-item tersebut. Namun, metode ini mengabaikan adanya kesalahan pengukuran (measurement error). Jika kita tidak memperhitungkan kesalahan pengukuran tersebut maka koefisien jalur dapat menjadi bias (Smith \& Langfield-Smith, 2004). Selain itu, SEM mampu menguji penelitian yang kompleks dan banyak variabel simultan. SEM dapat menyelesaikan analisis dengan satu kali estimasi di mana yang lain diselesaikan dengan beberapa persamaan regresi. SEM dapat melakukan analisis faktor dan regresi jalur sekaligus.

Structural Equation Model (SEM) atau model persamaan struktural merupakan teknik gabungan dari dua metodologi dari perspektif ekonometrika dengan memfokuskan pada prediksi dan psikometrika untuk menggambarkan konsep model berupa diagram jalur pada variabel laten dan diukur melalui indikator-indikatornya (Ghozali, 2013). Salah satu basis analisis SEM adalah Partial Least Square (PLS) yang merupakan metode analisis dengan menggunakan indikator-indikator skala kategori, ordinal, interval, dan rasio secara bersamaan untuk mengonfirmasi teori dan menjelaskan hubungan antara variabel latennya. Terdapat dua permodelan di dalam analisis PLS-SEM yaitu:

1) Model Pengukuran (Outer Model)

Model ini menunjukkan variabel manifest yang merepresentasikan variabel laten (Ghozali \& Latan, 2015). Adapun uji yang terdapat pada outer model yaitu:

a. Convergent Validity

Seperangkat indikator yang mewakili satu variabel laten dan yang mendasari variabel laten tersebut. Perwakilan tersebut dapat didemonstrasikan melalui unidimensionalitas yang dapat diekspresikan dengan menggunakan loading factor dan nilai rata-rata varian yang diekstraksi (Average Variance Extracted /AVE).

- Loading factor, merupakan korelasi yang dimiliki oleh indikator terhadap variabel latennya, semakin tinggi korelasi yang dihasilkan maka tingkat validitas yang dimiliki oleh indikator tersebut semakin bagus. Nilai faktor sebesar 0.7 dianggap memiliki validasi yang cukup kuat untuk menjelaskan konstruk laten.

- Average Variance Extracted (AVE), nilainya lebih besar dari 0.5 yang mempunyai arti bahwa satu variabel laten mampu menjelaskan lebih dari setengah varian dari indikatornya dalam rata-rata.

b. Composite Reliability

Uji yang digunakan untuk mengukur kestabilan dan konsistensi internal indikator. Nilai composite reliability untuk semua konstruk harus di atas 0.7 yang menunjukkan bahwa semua konstruk pada model yang diestimasi memenuhi kriteria discriminant validity.

c. Discriminant Validity

Uji yang digunakan untuk menunjukkan nilai korelasi indikator.

- Cross loading, digunakan untuk pengecekan validitas diskriminan. Jika suatu indikator mempunyai korelasi yang lebih tinggi dengan variabel laten lainnya daripada dengan variabel latennya sendiri maka kecocokan model harus dipertimbangkan ulang.

2) Model Struktural (Inner Model)

Uji pada model struktural menunjukkan kekuatan estimasi antarvariabel laten (Ghozali \& Latan, 2015). Ada beberapa uji untuk model struktural yaitu:

a. $\quad R$ Square pada konstruk endogen

Nilai $R$ Square berfungsi menjelaskan bagaimana pengaruh dari variabel eksogen terhadap variabel endogen. Nilai $R$ square sebesar 0.67 (kuat), 0.33 (moderat) dan 0.19 (lemah).

b. Koefisien jalur

Nilai koefisen jalur atau besarnya pengaruh konstruk laten sebagai pembuktian hipotesis. 


\section{Definisi Operasional}

Tabel 4 Definisi operasional

\begin{tabular}{|c|c|c|c|}
\hline No. & Variabel & Definisi Operasional Variabel & Sumber \\
\hline 1. & Jenis Kelamin & $\begin{array}{l}\text { Atribut fisiologis yang dimiliki. } \\
(D=0 \text { perempuan, } D=1 \text { laki-laki) }\end{array}$ & $\begin{array}{l}\text { Margaretha \& } \\
\text { Pambudhi } \\
\text { (2015) }\end{array}$ \\
\hline 2. & Universitas & $\begin{array}{l}\text { Bagian dari perguruan tinggi yang mempelajari } \\
\text { bidang ilmu tertentu. } \\
\text { ( } D=0 \text { IPB, } D=1 \text { Universitas Pakuan, } D=2 \text { Universitas } \\
\text { Juanda) }\end{array}$ & $\begin{array}{l}\text { Akmal } \\
\& \text { Saputra } \\
\text { (2016) }\end{array}$ \\
\hline 3. & $\begin{array}{l}\text { IPK (Indeks } \\
\text { Prestasi } \\
\text { Kumulatif) }\end{array}$ & $\begin{array}{l}\text { Nilai rata-rata dari keseluruhan mata kuliah yang } \\
\text { telah diambil. } \\
(0<\text { IPK }<4)\end{array}$ & Fadhly (2019) \\
\hline 4. & Sumber Informasi & $\begin{array}{l}\text { Sumber dalam memperoleh informasi keuangan. } \\
(D=1 \text { keluarga/saudara, } D=2 \text { teman/oranglain, } D=3 \\
\text { media, } D=4 \text { sekolah/instansi) }\end{array}$ & $\begin{array}{l}\text { Ameliawati \& } \\
\text { Setiyani } \\
\text { (2018) }\end{array}$ \\
\hline 5. & $\begin{array}{l}\text { Tingkat } \\
\text { Religiusitas }\end{array}$ & $\begin{array}{l}\text { Aspek rohani yang dimiliki setiap individu dan sangat } \\
\text { dipatuhi sebagai pedoman hidup serta tercermin pada } \\
\text { perilaku sehari-hari. } \\
(0<\text { Religiusitas }<40)\end{array}$ & $\begin{array}{l}\text { Dewantara } \\
(2014)\end{array}$ \\
\hline
\end{tabular}

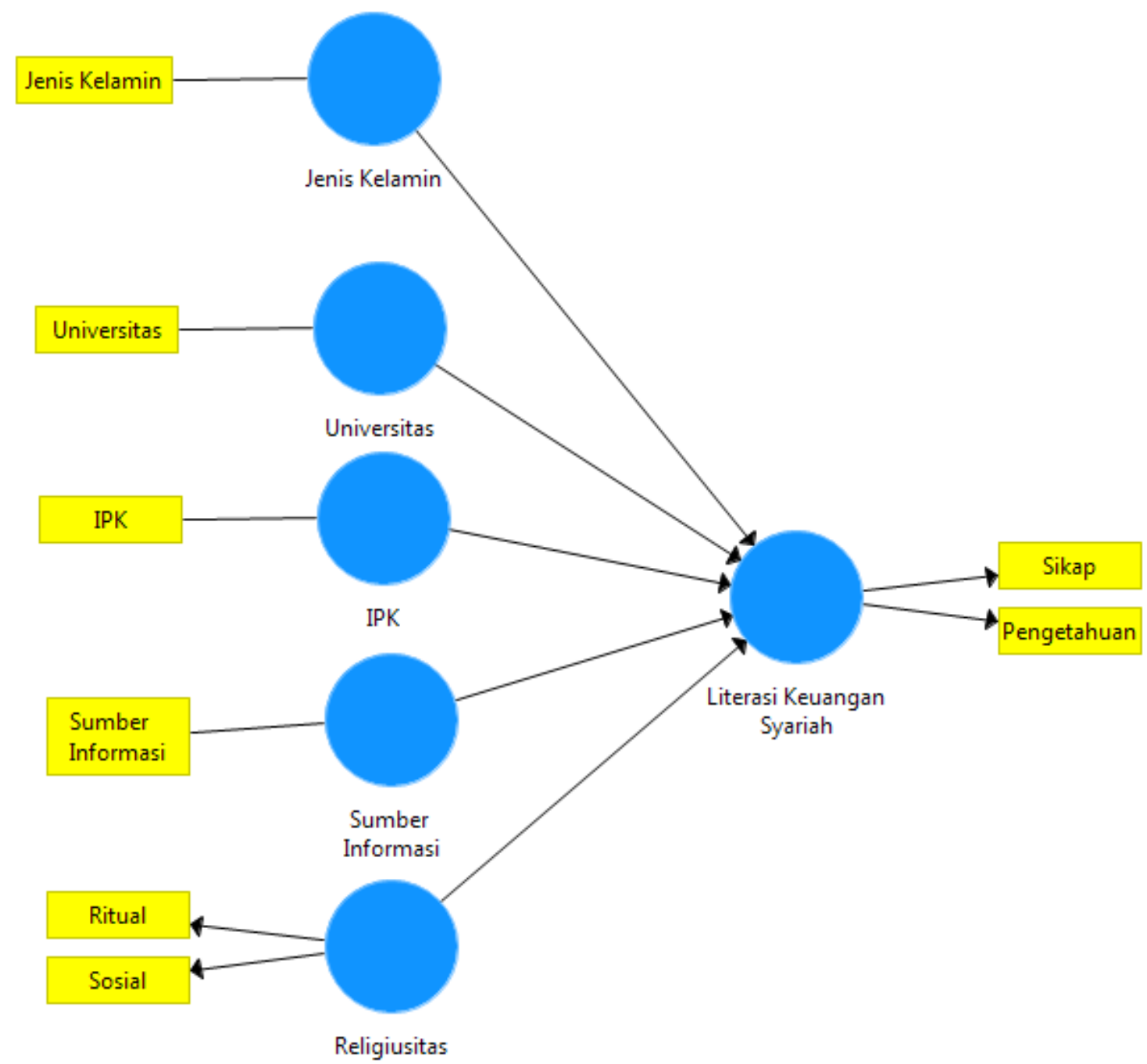

Gambar 2 Visualisasi model awal penelitian 


\section{HASIL DAN PEMBAHASAN}

\section{Karakteristik Responden}

Responden pada penelitian ini berjumlah 150 mahasiswa Muslim yang terdiri dari mahasiswa Institut Pertanian Bogor (IPB), Universitas Pakuan dan Universitas Juanda. Karakteristik responden meliputi jenis kelamin, Universitas, IPK, sumber informasi, dan religiusitas.

Tabel 5 Karakteristik responden berdasarkan kuesioner

\begin{tabular}{lccc}
\hline \multicolumn{1}{c}{ Karakteristik } & Keterangan & Jumlah (orang) & Persentase (\%) \\
\hline Jenis Kelamin & Laki-laki & 75 & 50 \\
& Perempuan & 75 & 50 \\
\hline \multirow{3}{*}{ Universitas } & Institut Pertanian Bogor & 83 & 55.3 \\
& Universitas Pakuan & 51 & 34 \\
& Universitas Juanda & 16 & 10.7 \\
\hline \multirow{3}{*}{ IPK } & $2.00 \leq$ IPK $<2.75$ & 24 & 16 \\
& $2.76 \leq$ IPK $<3.50$ & 97 & 64.7 \\
& $\geq 3.51$ & 29 & 19.3 \\
\hline \multirow{3}{*}{ Sumber Informasi } & Keluarga/saudara & 64 & 42.7 \\
& Teman/orang lain & 32 & 21.3 \\
& Media (elektronik, cetak) & 47 & 31.3 \\
& Instansi/karyawan bank & 7 & 4.7 \\
\hline \multirow{3}{*}{ Religiusitas } & Sangat Religius & 86 & 57.3 \\
& Religius & 62 & 41.3 \\
\hline Sin & Cukup Religius & 2 & 1.4 \\
\hline
\end{tabular}

Sumber: Data primer, 2020 (diolah)

Tabel 5 menunjukkan bahwa pengisian kuesioner yang didapatkan dari 150 responden bertujuan untuk mengetahui karakteristik yang dibutuhkan untuk proses penelitian. Jumlah responden laki-laki dan perempuan memiliki jumlah yang seimbang, yaitu masing-masing sebanyak 75 orang. Jumlah responden paling banyak berasal dari Institut Pertanian Bogor yang berjumlah 83 orang, diikuti dengan Universitas Pakuan yang berjumlah 51 orang, dan terakhir yaitu Universitas Juanda yang berjumlah 16 orang.

Responden didominasi oleh mahasiswa angkatan 2017 atau mahasiswa semester 6. Pada karakteristik IPK, responden didominasi oleh mahasiswa dengan IPK pada range $2.76 \leq$ IPK $<3.51$ yaitu sejumlah 97 orang, 29 orang dengan IPK $\geq 3.51$ dan 24 orang dengan IPK pada range $2.00 \leq$ IPK $<2.76$. Selain itu, sumber informasi responden dalam memperoleh berita terkait dengan keuangan syariah yaitu sebanyak 64 orang memperoleh informasi keuangan syariah dari media, 47 orang memperoleh informasi keuangan syariah dari keluarga, 32 orang memperoleh informasi keuangan syariah dari teman sebaya ataupun orang lain, dan 7 orang memperoleh informasi keuangan syariah dari lembaga pendidikan. Mayoritas mahasiswa atau sebesar $31.3 \%$ memperoleh informasi keuangan syariah dari media yaitu media elektronik berupa internet yang diakses melalui smartphone. Hal ini sesuai dengan hasil survei Asosiasi Penyelenggara Jasa Internet Indonesia (APJII) tentang penetrasi pengguna internet 2018 berdasarkan umur, di mana 88.5\% dari masyarakat berusia 20 hingga 24 tahun adalah pengguna internet, dan hanya $11.5 \%$ yang bukan pengguna internet. 
Tabel 6 Karakteristik responden berdasarkan bank konvensional dan bank syariah

\begin{tabular}{|c|c|c|c|c|c|}
\hline Karakteristik & Keterangan & $\begin{array}{l}\text { Bank } \\
\text { Syariah } \\
\text { (orang) }\end{array}$ & $\begin{array}{c}\text { Persentase } \\
(\%)\end{array}$ & $\begin{array}{c}\text { Bank } \\
\text { Konvensional } \\
\text { (orang) }\end{array}$ & $\begin{array}{c}\text { Persentase } \\
(\%)\end{array}$ \\
\hline Tabungan & & 42 & 26.6 & 116 & 73.4 \\
\hline Jenis & Laki-laki & 27 & 64.3 & 66 & 56.9 \\
\hline Kelamin & Perempuan & 15 & 35.7 & 50 & 43.1 \\
\hline \multirow[t]{3}{*}{ Universitas } & Institut Pertanian Bogor & 22 & 52.4 & 70 & 60.3 \\
\hline & Universitas Pakuan & 13 & 30.9 & 33 & 28.5 \\
\hline & Universitas Juanda & 7 & 16.7 & 13 & 11.2 \\
\hline \multirow[t]{3}{*}{ IPK } & $2.00 \leq \mathrm{IPK}<2.75$ & 3 & 7.2 & 20 & 17.2 \\
\hline & $2.76 \leq \mathrm{IPK}<3.50$ & 29 & 69 & 75 & 64.7 \\
\hline & $\geq 3.51$ & 10 & 23.8 & 21 & 18.1 \\
\hline Sumber & Keluarga/saudara & 26 & 61.9 & 49 & 42.3 \\
\hline \multirow[t]{3}{*}{ Informasi } & Teman/orang lain & 7 & 16.7 & 23 & 19.8 \\
\hline & Media (elektronik, cetak) & 5 & 11.9 & 41 & 35.3 \\
\hline & Instansi/karyawan bank & 4 & 9.5 & 3 & 2.6 \\
\hline \multirow[t]{3}{*}{ Religiusitas } & Sangat Religius & 31 & 73.8 & 75 & 64.7 \\
\hline & Religius & 11 & 26.2 & 40 & 34.5 \\
\hline & Cukup Religius & - & - & 1 & 0.8 \\
\hline
\end{tabular}

Sumber: Data primer, 2020 (diolah)

Tabel 6 menunjukkan bahwa 42 dari 150 responden atau sebesar $28 \%$ memiliki tabungan di bank syariah dan 116 dari 150 responden memiliki tabungan di bank konvensional. Jumlah responden lakilaki yang memiliki tabungan di bank syariah yaitu sebanyak 27 orang dan pada bank konvensional sebanyak 66 orang. Jauh berbeda dengan jumlah responden perempuan yang memiliki tabungan di bank syariah yaitu sebanyak 15 orang dan yang memiliki tabungan di bank konvensional yaitu sebanyak 50 orang.

Penyebaran jumlah responden Institut Pertanian Bogor yang memiliki tabungan di bank syariah dan bank konvensional yaitu masing-masing sebanyak 22 dan 70 orang. Responden di Universitas Pakuan yang memiliki tabungan di bank syariah yaitu sebanyak 13 orang dan yang memiliki tabungan pada bank konvensional sebanyak 33 orang. Selanjutnya, responden di Universitas Juanda yang memiliki tabungan di bank syariah yaitu sebanyak 7 orang dan bank konvensional sebanyak 13 orang. Pada karakteristik IPK, mahasiswa dengan IPK pada range $2.00 \leq$ IPK $<2$ yang memiliki tabungan di bank syariah dan bank konvensional yaitu masing-masing sebanyak 3 dan 20 orang. Mahasiswa dengan IPK pada range $2.76 \leq$ IPK $<3.51$ yang memiliki tabungan di bank syariah dan bank konvensional yaitu masing-masing sebanyak 29 dan 75 orang. Mahasiswa dengan IPK $\geq 3.51$ yang memiliki tabungan di bank syariah dan bank konvensional yaitu masing-masing sebanyak 10 dan 21 orang.

Responden yang mendapatkan informasi dari keluarga terkait dengan literasi keuangan, memiliki tabungan di bank syariah sebanyak 26 orang dan pada bank konvensional sebanyak 49 orang. Responden yang mendapatkan informasi dari teman/orang lain terkait dengan literasi keuangan, memiliki tabungan di bank syariah sebanyak 7 orang dan pada bank konvensional sebanyak 23 orang. Responden yang mendapatkan informasi dari media (elektronik, cetak), memiliki tabungan di bank syariah sebanyak 5 orang dan pada bank konvensional sebanyak 41 orang. Total responden yang mendapatkan informasi dari instansi/karyawan bank terkait dengan literasi keuangan, memiliki tabungan di bank syariah sebanyak 7 orang dan pada bank konvensional sebanyak 23 orang.

Karakteristik mahasiswa sangat religius yang memiliki tabungan di bank syariah yaitu sebanyak 27 orang dan pada bank konvensional sebanyak 66 orang. Total mahasiswa yang memiliki karakteristik religius yang memiliki tabungan di bank syariah yaitu sebanyak 11 orang dan pada bank konvensional sebanyak 40 orang. Dan mahasiswa yang tergolong cukup religius hanya ada 1 orang yang menabung di bank konvensional. 


\section{Tingkat Literasi Keuangan Syariah Mahasiswa Muslim Angkatan 2017 di Bogor}

Tingkat literasi keuangan syariah mahasiswa diperoleh dari hasil pengisian kuesioner oleh 150 mahasiswa Muslim di Bogor. Tingkat literasi keuangan syariah mahasiswa Muslim di Bogor divisualisasikan pada Gambar 2.

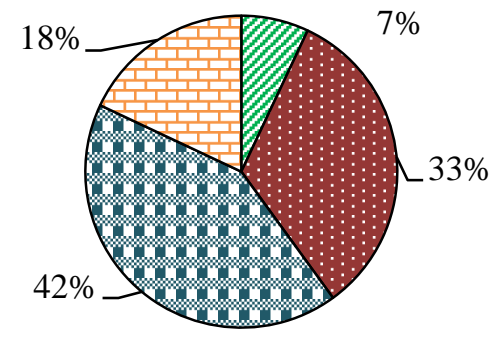

$\square$ Well Literate $\square$ Sufficient Literate 圆Less Literate $\square$ Not Literate

Sumber: Data primer, 2020 (diolah)

Gambar 3 Tingkat literasi keuangan syariah mahasiswa Muslim di Bogor

Gambar 3 menunjukkan tingkat literasi keuangan syariah mahasiswa Muslim di Bogor terbagi menjadi 4 kategori. Terdapat 7\% dari keseluruhan responden termasuk ke kategori well literate, terdapat 33\% dari keseluruhan responden termasuk ke kategori sufficient literate, terdapat $42 \%$ responden termasuk ke kategori less literate, dan terdapat $18 \%$ responden termasuk ke kategori not literate. Rata-rata tingkat literasi keuangan syariah mahasiswa Muslim di Bogor adalah sebesar 50.2\% atau rata-rata hanya dapat menjawab 10 dari 21 pertanyaan dengan benar. Hal ini menunjukkan bahwa tingkat literasi keuangan syariah mahasiswa Muslim di Bogor termasuk ke dalam kategori sufficient literate. Nilai tertinggi yang mampu diperoleh responden adalah sebesar $83.33 \%$ dan nilai terendah adalah sebesar $13.33 \%$.

Terdapat $7 \%$ dari keseluruhan responden atau sebanyak 11 dari 150 orang yang tergolong well literate. Kategori ini didominasi oleh mahasiswa Universitas Pakuan dengan IPK $2.76 \leq$ IPK $<3.50$. Seseorang dikatakan well literate apabila telah memiliki pengetahuan dan keyakinan tentang lembaga jasa keuangan serta produk jasa keuangan, termasuk fitur, manfaat dan risiko, hak dan kewajiban terkait produk dan jasa keuangan, serta memiliki keterampilan dalam menggunakan produk dan jasa keuangan. Pada kategori ini, mayoritas responden sudah mengetahui seluruh produk dan jasa keuangan syariah yang ditanyakan pada kuesioner yaitu tabungan, deposito syariah, kartu kredit syariah, reksadana syariah, asuransi syariah, dana pensiun syariah, obligasi syariah (sukuk), gadai (rahn) dan giro syariah. Produk dan jasa keuangan yang paling banyak dimiliki responden yaitu tabungan sebesar $42.85 \%$.

Sebanyak 33\% dari keseluruhan responden atau sebanyak 49 dari 150 orang termasuk ke kategori sufficient literate. Kategori ini didominasi oleh mahasiswa Universitas Juanda dengan IPK pada range $2.76 \leq$ IPK $<3.51$. Seseorang akan dikategorikan sufficient literate apabila memiliki pengetahuan dan keyakinan tentang lembaga jasa keuangan serta produk dan jasa keuangan, termasuk fitur, manfaat dan risiko, hak dan kewajiban terkait produk dan jasa keuangan tetapi belum memiliki keterampilan dalam menggunakan produk dan layanan jasa keuangan tersebut. Mayoritas responden sudah mengetahui seluruh produk dan jasa keuangan syariah yang ditanyakan pada kuesioner yaitu tabungan, deposito syariah, kartu kredit syariah, reksadana syariah, asuransi syariah, dana pensiun syariah, obligasi syariah (sukuk), gadai ( $\mathrm{rahn}$ ) dan giro syariah. Produk dan jasa keuangan yang paling banyak dimiliki responden yaitu tabungan sebesar $29.54 \%$, kartu kredit syariah dan gadai (rahn) masing-masing sebesar $4.54 \%$, serta asuransi syariah dan giro syariah masing-masing sebesar $2.27 \%$. 
Terdapat 42\% responden yang termasuk ke dalam kategori less literate, yaitu sebanyak 63 dari 150 orang. Kategori ini didominasi oleh mahasiswa Institut Pertanian Bogor dengan IPK pada kisaran 2.76 $\leq$ IPK $<3.51$. Seseorang dikategorikan less literate apabila hanya memiliki pengetahuan tentang lembaga jasa keuangan, produk dan jasa keuangan, belum memiliki keyakinan tentang produk dan lembaga jasa keuangan dan belum memahami fitur, manfaat dan risiko, serta hak dan kewajiban terkait produk dan jasa keuangan. Mayoritas responden sudah mengetahui seluruh produk dan jasa keuangan syariah yang ditanyakan pada kuesioner yaitu tabungan, deposito syariah, kartu kredit syariah, reksadana syariah, asuransi syariah, dana pensiun syariah, obligasi syariah (sukuk), gadai (rahn) dan giro syariah. Produk dan jasa keuangan yang paling banyak dimiliki responden yaitu tabungan sebesar $45.55 \%$, dan deposito syariah, kartu kredit syariah, reksadana syariah, asuransi syariah, dana pensiun syariah, obligasi syariah (sukuk) masing-masing sebesar $1.11 \%$.

Terdapat $18 \%$ responden yang termasuk ke dalam kategori not literate, yaitu sebanyak 27 dari 150 orang. Kategori ini didominasi mahasiswa Institut Pertanian Bogor dengan IPK pada kisaran $2.76 \leq$ IPK < 3.51. Seseorang dikategorikan not literate di mana seseorang tidak memiliki pengetahuan, keyakinan dan keterampilan terhadap produk dan lembaga jasa keuangan. Hal ini dapat dibuktikan dengan jawaban responden di mana mayoritas responden belum mengetahui dan memiliki produkproduk dan jasa keuangan.

\section{Tingkat Literasi Keuangan Syariah Mahasiswa Muslim Angkatan 2017 di Bogor Berdasarkan Indikator}

Tingkat literasi keuangan syariah mahasiswa Muslim di Bogor berdasarkan setiap aspek dan indikator secara lebih rinci dijelaskan pada Tabel 7. Berdasarkan Tabel 7, rata-rata tingkat literasi keuangan mahasiswa berdasarkan indikator sikap dan perilaku keuangan sebesar $24.33 \%$ dan tergolong not literate, sehingga dapat dikatakan bahwa sikap dan perilaku keuangan syariah mahasiswa kurang baik. Rata-rata tingkat literasi keuangan syariah mahasiswa berdasarkan indikator pengetahuan keuangan sebesar $76.07 \%$ dan tergolong well literate, sehingga dapat dikatakan bahwa perilaku keuangan syariah mahasiswa sudah baik.

Tabel 7 menunjukkan rata-rata tingkat literasi keuangan syariah mahasiswa Muslim di Bogor adalah sebesar 50.2\% atau rata-rata hanya dapat menjawab 10 dari 21 pertanyaan dengan benar. Hal ini menunjukkan bahwa tingkat literasi keuangan syariah mahasiswa Muslim di Bogor termasuk ke kategori sufficient literate. Nilai tertinggi yang mampu diperoleh responden adalah sebesar $88.33 \%$ dan nilai terendah adalah sebesar $13.33 \%$.

Rata-rata tingkat literasi keuangan syariah mahasiswa berdasarkan indikator sikap dan perilaku keuangan tergolong not literate (24.33\%), tetapi hampir mendekati kategori less literate. Nilai tertinggi terdapat pada aspek keputusan keuangan (34\%) di mana mayoritas mahasiswa harus menulis tujuan keuangan yang membantu untuk menentukan prioritas pengeluaran dan menurut mahasiswa memiliki rencana keuangan membuat sulit untuk mengambil keputusan investasi dalam keuangan. Selanjutnya diikuti oleh aspek pengembangan dan perencanaan keuangan (28.67\%). Mayoritas mahasiswa berpikir secara finansial di mana dalam 5 atau 10 tahun ke depan penting untuk mencapai kesuksesan finansial. Nilai terendah terdapat pada aspek pengelolaan anggaran (13.33\%) karena menurut mahasiswa berkonsentrasi pada masa kini ketika mengelola keuangan tidak benar dan menabung sangat penting. Selanjutnya adalah aspek rencana keuangan (18\%). Hal ini disebabkan anggaran tertulis sangat penting untuk manajemen keuangan yang sukses dan memiliki rencana tabungan tidak benar-benar diperlukan untuk memenuhi kebutuhan keuangan seseorang saat ini saja.

Rata-rata tingkat literasi keuangan syariah mahasiswa berdasarkan indikator pengetahuan keuangan tergolong well literate (76.07\%) sehingga dapat dikatakan bahwa perilaku keuangan syariah mahasiswa tergolong sudah baik. Nilai tertinggi terdapat pada pertanyaan mengenai jumlah keuangan (88.33\%) di mana mayoritas mahasiswa menghitung secara tepat jawaban yang ditanyakan. Selanjutnya diikuti oleh pertanyaan mengenai akad dalam perbankan (83.33\%). Mayoritas mahasiswa menjawab benar mengenai akad yang ditanyakan pada kuesioner. 
Tabel 7 Tingkat literasi keuangan berdasarkan setiap indikator

\section{Tingkat Literasi Keuangan Syariah (\%)}

$\begin{array}{lcccc} & \text { Keterangan } & \text { Less } & \text { Sufficient } & \text { Well Literate } \\ \text { No. } & \text { Literate } & \text { Literate } & \text { Literate } & (\mathbf{7 5 - 1 0 0 )} \\ & (\mathbf{0 - 2 5}) & (\mathbf{2 5 - 5 0 )} & (\mathbf{5 0 - 7 5}) & \end{array}$

\begin{tabular}{|c|c|c|c|}
\hline \multicolumn{4}{|c|}{ Indikator 1: Sikap dan Perilaku Keuangan } \\
\hline 1. & $\begin{array}{l}\text { Mengembangkan pola menabung yang } \\
\text { teratur }\end{array}$ & & 28.67 \\
\hline 2. & Menulis tujuan keuangan & & 34 \\
\hline 3. & $\begin{array}{l}\text { Anggaran tertulis untuk keuangan yang } \\
\text { sukses }\end{array}$ & 18 & \\
\hline 4. & $\begin{array}{l}\text { Merencanakan untuk menghabiskan } \\
\text { uang }\end{array}$ & 23.33 & \\
\hline 5. & Berpikir secara finansial ke depan & & 28.67 \\
\hline 6. & $\begin{array}{l}\text { Berkonsentrasi pada masa kini ketika } \\
\text { mengelola keuangan }\end{array}$ & 13.33 & \\
\hline 7. & Perencanaan keuangan untuk pensiun & & 28.67 \\
\hline 8. & $\begin{array}{l}\text { Rencana keuangan membuat sulit untuk } \\
\text { mengambil keputusan }\end{array}$ & & 34 \\
\hline 9. & $\begin{array}{l}\text { Rencana tabungan tidak benar-benar } \\
\text { diperlukan }\end{array}$ & 18 & \\
\hline 10. & $\begin{array}{l}\text { Perencanaan tidak perlu untuk bertahan } \\
\text { hari ini }\end{array}$ & 23.33 & \\
\hline 11. & $\begin{array}{l}\text { Menyimpan catatan masalah keuangan } \\
\text { memakan waktu }\end{array}$ & & 28.67 \\
\hline & Menabung tidak terlalu penting & 13.33 & \\
\hline & Rata-rata Indikator 1 & 24.33 & \\
\hline
\end{tabular}

\begin{tabular}{|c|c|c|c|}
\hline \multicolumn{4}{|c|}{ Indikator 2: Pengetahuan Keuangan } \\
\hline 1. & Fungsi Dewan Pengawas Syariah (DPS) & & 83.33 \\
\hline 2. & Akad perbankan syariah (Wadi'ah) & 68.67 & \\
\hline 3. & Akad perbankan syariah (Mudharabah) & & 83.33 \\
\hline 4 . & Akad perbankan syariah (Musyarakah) & 70 & \\
\hline 5 . & Prinsip perbankan syariah & & 83.33 \\
\hline 6. & Jumlah uang & 74 & \\
\hline 7. & Menghitung persentase bagi hasil & & 83.33 \\
\hline 8 . & Menghitung total pendapatan & 70 & \\
\hline 9 . & Perbandingan nilai uang & 68.67 & \\
\hline & Rata-rata Indikator 2 & & 76.07 \\
\hline & $\begin{array}{l}\text { Rata-Rata Tingkat Literasi Keuangan } \\
\text { Syariah }\end{array}$ & 50.2 & \\
\hline
\end{tabular}

Sumber: Data primer, 2020 (diolah)

\section{Tingkat Literasi Keuangan Syariah Mahasiswa Muslim Angkatan 2017 di Bogor Berdasarkan Variabel}

Tingkat literasi keuangan syariah mahasiswa Muslim di Bogor berdasarkan setiap variabel secara lebih rinci dijelaskan pada Tabel 8. Berdasarkan Tabel 8, rata-rata tingkat literasi keuangan mahasiswa berdasarkan variabel jenis kelamin didominasi oleh laki-laki sebesar $38.7 \%$, variabel 
universitas didominasi oleh Universitas Juanda sebesar 56.4\%, variabel IPK didominasi oleh kategori $2.76 \leq \mathrm{IPK}<3.50$, variabel sumber informasi didominasi oleh keluarga/saudara sebesar $17.3 \%$, dan variabel religiusitas didominasi oleh mahasiswa yang sangat religius.

Tabel 8 Tingkat literasi keuangan berdasarkan setiap variabel

\begin{tabular}{|c|c|c|c|c|c|}
\hline \multirow[b]{2}{*}{ No. } & \multirow[b]{2}{*}{ Keterangan } & \multicolumn{4}{|c|}{ Tingkat Literasi Keuangan Syariah (\%) } \\
\hline & & $\begin{array}{c}\text { Not } \\
\text { Literate } \\
(0-25)\end{array}$ & $\begin{array}{c}\text { Less } \\
\text { Literate } \\
(25-50)\end{array}$ & $\begin{array}{c}\text { Sufficient } \\
\text { Literate } \\
(50-75)\end{array}$ & $\begin{array}{c}\text { Well } \\
\text { Literate } \\
(75-100)\end{array}$ \\
\hline \multicolumn{6}{|c|}{ Variabel 1: Jenis Kelamin } \\
\hline 1. & Laki-Laki & 17.3 & 37.3 & 38.7 & 6.7 \\
\hline 2. & Perempuan & 18.7 & 45.3 & 28 & 8 \\
\hline \multicolumn{6}{|c|}{ Variabel 2: Universitas } \\
\hline 1. & Institut Pertanian Bogor & 20.5 & 50.6 & 21.7 & 7.2 \\
\hline 2. & Universitas Pakuan & 17.6 & 31.4 & 43.2 & 7.8 \\
\hline 3. & Universitas Juanda & 6.2 & 31.2 & 56.4 & 6.2 \\
\hline \multicolumn{6}{|c|}{ Varibel 3: IPK } \\
\hline 1. & $2.00 \leq \mathrm{IPK}<2.75$ & 1.3 & 6 & 5.3 & 3.3 \\
\hline 2. & $2.76 \leq \mathrm{IPK}<3.50$ & 5.3 & 20.7 & 26.7 & 11.3 \\
\hline 3. & $\geq 3.51$ & 0.7 & 6 & 10.1 & 3.3 \\
\hline \multicolumn{6}{|c|}{ Variabel 4: Sumber Informasi } \\
\hline 1. & Keluarga/saudara & 8.7 & 17.3 & 14.7 & 2 \\
\hline 2. & Teman/orang lain & 5.3 & 8.7 & 6 & 1.3 \\
\hline 3. & Media (elektronik, cetak, dll) & 4 & 13.3 & 12 & 2 \\
\hline 4. & Sekolah/Instansi tempat bekerja & - & 2.7 & - & 2 \\
\hline \multicolumn{6}{|c|}{ Variabel 5: Religiusitas } \\
\hline 1. & Sangat religious & 7.3 & 24.7 & 20.6 & 4.7 \\
\hline 2. & Religius & 10 & 17.3 & 11.3 & 2.7 \\
\hline 3. & Cukup religious & - & 0.7 & - & 0.7 \\
\hline
\end{tabular}

Sumber: Data primer, 2020 (diolah)

Tabel 8 menunjukkan tingkat literasi keuangan berdasarkan setiap variabel yaitu jenis kelamin, universitas, IPK, sumber informasi, dan religiusitas. Pada variabel jenis kelamin, jumlah mahasiswa laki-laki yang memiliki tingkat literasi yang termasuk ke dalam kategori well literate sebesar $6.7 \%$ atau sebanyak 5 orang, kategori sufficient literate sebesar $38.7 \%$ atau sebanyak 29 orang, kategori less literate sebesar $37.3 \%$ atau sebanyak 28 orang, dan not literate sebesar $17.3 \%$ atau sebanyak 13 orang. Jumlah mahasiswa perempuan yang memiliki tingkat literasi yang termasuk ke dalam kategori well literate sebesar $8 \%$ atau sebanyak 6 orang, kategori sufficient literate sebesar $28 \%$ atau sebanyak 21 orang, kategori less literate sebesar $45.3 \%$ atau sebanyak 34 orang, dan not literate sebesar $18.7 \%$ atau sebanyak 14 orang.

Variabel universitas terbagi menjadi tiga yaitu Institut Pertanian Bogor, Universitas Pakuan dan Universitas Juanda. Tingkat literasi mahasiswa di Institut Pertanian Bogor yang termasuk ke dalam kategori well literate sebesar $7.2 \%$ atau sebanyak 6 orang, kategori sufficient literate sebesar $21.7 \%$ atau sebanyak 18 orang, kategori less literate sebesar 50.6\% atau sebanyak 42 orang, dan not literate sebesar 20.5\% atau sebanyak 17 orang. Jumlah mahasiswa Universitas Pakuan yang termasuk ke dalam kategori well literate sebesar $7.8 \%$ atau sebanyak 4 orang, kategori sufficient literate sebesar $43.2 \%$ atau sebanyak 22 orang, kategori less literate sebesar $31.4 \%$ atau sebanyak 16 orang, dan not literate sebesar $17.6 \%$ atau sebanyak 9 orang. 
Pada variabel IPK terbagi menjadi 3 yaitu $2.00 \leq$ IPK $<2.75,2.76 \leq$ IPK $<3.50$, dan $\geq 3.51$. Tingkat literasi mahasiswa dengan IPK pada range $2.00 \leq$ IPK $<2.75$ yang termasuk ke dalam kategori well literate sebanyak 5 orang, kategori sufficient literate sebanyak 8 orang, kategori less literate sebanyak 9 orang, dan not literate sebanyak 2 orang. Tingkat literasi mahasiswa dengan IPK pada range $2.76 \leq$ IPK $<3.50$ yang termasuk ke dalam kategori well literate sebanyak 17 orang, kategori sufficient literate sebanyak 40 orang, kategori less literate sebanyak 31 orang, dan not literate sebanyak 8 orang. Tingkat literasi mahasiswa dengan IPK pada range $\geq 3.51$ yang termasuk ke dalam kategori well literate sebanyak 5 orang, kategori sufficient literate sebanyak 15 orang, kategori less literate sebanyak 9 orang, dan not literate sebanyak 1 orang.

Sumber informasi yang didapatkan mahasiswa terbagi menjadi empat yaitu keluarga/saudara, teman/ orang lain, media (elektronik, cetak, dll), dan sekolah/instansi tempat bekerja. Sumber informasi keuangan mahasiswa didapatkan dari keluarga/saudara yang termasuk ke dalam kategori well literate sebanyak 3 orang, kategori sufficient literate sebanyak 22 orang, kategori less literate sebanyak 26 orang, dan not literate sebanyak 13 orang. Sumber informasi keuangan mahasiswa didapatkan dari teman/orang lain yang termasuk ke dalam kategori well literate sebanyak 2 orang, kategori sufficient literate sebanyak 9 orang, kategori less literate sebanyak 13 orang, dan not literate sebanyak 8 orang. Sumber informasi keuangan mahasiswa didapatkan dari media (elektronik, cetak, dll) yang termasuk ke dalam kategori well literate sebanyak 3 orang, kategori sufficient literate sebanyak 18 orang, kategori less literate sebanyak 20 orang, dan not literate sebanyak 6 orang. Sumber informasi keuangan mahasiswa didapatkan dari sekolah/instansi tempat bekerja yang termasuk ke dalam kategori well literate sebanyak 3 orang, dan kategori less literate sebanyak 4 orang.

Variabel religiusitas terbagi menjadi tiga yaitu sangat religius, religius, dan cukup religius. Tingkat literasi mahasiswa pada kategori sangat religius yang termasuk ke dalam kategori well literate sebanyak 7 orang, kategori sufficient literate sebanyak 31 orang, kategori less literate sebanyak 37 orang, dan not literate sebanyak 11 orang. Tingkat literasi mahasiswa pada kategori religius yang termasuk ke dalam kategori well literate sebanyak 4 orang, kategori sufficient literate sebanyak 17 orang, kategori less literate sebanyak 26 orang, dan not literate sebanyak 15 orang. Tingkat literasi mahasiswa pada kategori cukup religius yang termasuk ke dalam kategori well literate sebanyak 1 orang, dan kategori less literate sebanyak 1 orang.

\section{Faktor-Faktor yang Memengaruhi Literasi Keuangan Syariah Mahasiswa Muslim Angkatan 2017 di Bogor}

\section{Analisis model pengukuran (outer model)}

Evaluasi model pengukuran atau outer model adalah mengevaluasi hubungan yang dimiliki oleh variabel laten beserta indikatornya (Yamin \& Kurniawan, 2011). Model dalam penelitian ini menggambarkan sejauh mana peubah indikator mampu mencerminkan peubah variabel laten.

1) Convergent Validity

Convergent validity yang digunakan dalam penelitian ini apabila memiliki nilai loading factor di atas 0.7. Namun apabila nilai loading faktor berkisar antara 0.5 hingga 0.6 masih dapat diterima (Ghozali, 2011). Nilai AVE dapat diterima jika nilai lebih besar dari 0.50. Besar nilai outer loading pada setiap indikator dapat dilihat pada Tabel 9. 
Tabel 9 Nilai outer loading dan AVE

\begin{tabular}{lccc}
\hline Variabel Laten & Indikator & Outer Loading & $\begin{array}{c}\text { Average Variance } \\
\text { Extracted (AVE) }\end{array}$ \\
\hline Eksogen & & & \\
\hline Jenis Kelamin & $\mathrm{X} 1$ & 1.000 & 1.000 \\
Universitas & $\mathrm{X} 2$ & 1.000 & 1.000 \\
IPK & $\mathrm{X} 3$ & 1.000 & 1.000 \\
Sumber Informasi & $\mathrm{X} 4$ & 1.000 & 1.000 \\
Religiusitas & $\mathrm{X} 51$ & 0.721 & 0.717 \\
& $\mathrm{X} 52$ & 0.956 & 0.713 \\
\hline Endogen & & & \\
\hline Sikap dan Perilaku Keuangan & $\mathrm{Y} 1$ & 0.840 & \\
Pengetahuan Keuangan & $\mathrm{Y} 2$ & 0.849 & \\
\hline Sumber: Data primer, 2020 (diolah) & & &
\end{tabular}

Berdasarkan hasil analisis seluruh indikator dapat menggambarkan variabel dan dinyatakan valid. Pada variabel laten literasi keuangan syariah, indikator pengetahuan keuangan (Y2) memiliki nilai outer loading yang lebih besar dibandingkan dengan indikator sikap dan perilaku keuangan. Hal ini menunjukkan bahwa indikator pengetahuan keuangan lebih dominan dalam menggambarkan literasi keuangan mahasiswa.

2) Composite reliability

Uji reliabilitas variabel laten dikatakan reliabel apabila memiliki nilai composite reliability di atas 0.7. Dari Tabel 10 dapat disimpulkan bahwa semua variabel memiliki nilai composite reliability di atas 0.7 . Jadi dapat disimpulkan bahwa variabel laten yang digunakan dalam penelitian ini memiliki reliabilitas yang bagus.

Tabel 10 Nilai composite reliability

\begin{tabular}{lc}
\hline Variabel & Composite Reliability \\
\hline Jenis Kelamin & 1.000 \\
Universitas & 1.000 \\
IPK & 1.000 \\
Sumber Informasi & 1.000 \\
Religiusitas & 0.832 \\
Literasi Keuangan & 0.833 \\
\hline
\end{tabular}

Sumber: Data primer, 2020 (diolah)

3) Discriminant Validity

Tahapan selanjutnya adalah melihat nilai cross loading dari indikator. Discriminant validity dikatakan bagus apabila indikator yang dimiliki oleh variabel laten memiliki nilai korelasi yang lebih tinggi dibandingkan dengan nilai korelasi terhadap variabel laten yang lain.

\section{Analisis model struktural (inner model)}

Analisis model struktural atau analisis pada inner model dilakukan untuk menganalisis pengaruh variabel-variabel laten eksogen terhadap variabel laten endogen.

1) Uji $R$ square

Uji $R$ square berfungsi untuk menjelaskan pengaruh variabel laten eksogen terhadap variabel endogen. Berdasarkan analisis diperoleh nilai $R$ Square sebesar 0.475 atau $47.5 \%$. Menurut Chin (1998) dalam Ghozali \& Latan (2015), nilai $R$ square sebesar 0.475 tersebut tergolong moderate. Artinya, variabel jenis kelamin, universitas, IPK, sumber informasi, dan religiusitas mampu menjelaskan literasi keuangan sebesar $47.5 \%$. 
2) Koefisien Jalur

Setelah melakukan evaluasi model pengukuran, tahap selanjutnya pada model struktural yaitu mengetahui apakah hipotesis dapat diterima atau ditolak. Penelitian ini menggunakan nilai signifikansi sebesar 0.05 atau 5\%. Hubungan antarvariabel akan signifikan apabila P-value lebih kecil daripada nilai signifikan yang telah ditetapkan $(\mathrm{P}<0.05)$. Hasil dari koefisien jalur dapat dilihat di Tabel 11. Dari Tabel 11 dapat disimpulkan bahwa terdapat beberapa jalur variabel yang tidak signifikan karena nilai T-statistiknya $<1.97$ (t-tabel) dan P-value memiliki nilai lebih dari 0.05 .

Tabel 11 Hasil koefisien jalur

\begin{tabular}{|c|c|c|c|c|c|}
\hline Variabel & $\begin{array}{c}\text { Original } \\
\text { Sample }\end{array}$ & $\begin{array}{c}T \\
\text { Statistics }\end{array}$ & $\begin{array}{c}P \\
\text { Value }\end{array}$ & Pengaruh & $\begin{array}{c}\text { Keputusan } \\
\text { Hipotesis }\end{array}$ \\
\hline Jenis & 0.562 & 11.233 & 0.000 & Berpengaruh signifikan & Tolak H0 \\
\hline Kelamin & & & & & \\
\hline Universitas & 0.405 & 6.762 & 0.000 & Berpengaruh signifikan & Tolak H0 \\
\hline IPK & 0.036 & 0.632 & 0.528 & Tidak signifikan & Terima H0 \\
\hline $\begin{array}{l}\text { Sumber } \\
\text { Informasi }\end{array}$ & 0.095 & 1.384 & 0.167 & Tidak signifikan & Terima H0 \\
\hline Religiusitas & 0.034 & 0.818 & 0.414 & Tidak signifikan & Terima $\mathrm{H} 0$ \\
\hline
\end{tabular}

Sumber: Data primer, 2020 (diolah)

Tabel 11 menunjukkan bahwa hasil penelitian pada variabel jenis kelamin sudah sesuai dengan hipotesis yang telah ditetapkan dan sejalan dengan penelitian. Menurut Chen \& Volpe (1998), tingkat literasi mahasiswa laki-laki lebih baik daripada mahasiswa perempuan disebabkan mahasiswa perempuan kurang antusias tentang topik keuangan, kurang percaya diri dan kurang bersedia untuk memperoleh keterampilan keuangan. Menurut Clark et al. (2006), banyak wanita mengakui kurangnya pengetahuan mereka, seperti yang ditunjukkan ketika ditanya untuk menjawab pertanyaan yang mengukur pengetahuan tentang konsep keuangan dasar, wanita lebih kecil kemungkinannya daripada pria untuk menjawab dengan benar dan lebih cenderung mengindikasikan bahwa mereka tidak tahu jawabannya. Berdasarkan fakta dan data yang terjadi di lapangan, mahasiswa perempuan lebih banyak kesalahan dalam menjawab pertanyaan kuesioner.

Pada variabel jenis kelamin, nilai 1 diberikan jika mahasiswa berjenis kelamin laki-laki dan nilai 0 diberikan jika mahasiswa berjenis kelamin perempuan. Diperoleh nilai $p$ value sebesar 0.000 , sehingga keputusan hipotesis yaitu tolak H0 karena $p$ value $<0.050$. Nilai original sample adalah sebesar 0.562 yang artinya variabel berpengaruh secara positif atau signifikan. Variabel berpengaruh secara positif, dapat dikatakan bahwa mahasiswa yang berjenis kelamin laki-laki memiliki literasi keuangan syariah yang lebih baik dibandingkan mahasiswa yang berjenis kelamin perempuan.

Hasil penelitian pada variabel universitas sudah sesuai dengan hipotesis yang telah ditetapkan dan sejalan dengan penelitian. Berdasarkan fakta dan data yang terjadi di lapangan, mahasiswa di Universitas Juanda memperoleh lebih banyak informasi terkait ilmu agama melalui pendidikan formal yaitu mata kuliah umum yang disebut mata kuliah pendidikan kampus bertauhid dan Pendidikan Agama Islam. Mata kuliah tersebut mempelajari nilai-nilai agama di antaranya mempelajari tentang tauhid, akhlak, fikih ibadah, fikih muamalah, tasawuf, ilmu kesehatan, manajemen sumberdaya insani berbasis tauhid dan kepemimpinan berbasis tauhid. Oleh karena itu, mahasiswa di Universitas Juanda lebih sadar untuk menggunakan lembaga keuangan yang berbasis syariah.

Variabel universitas, nilai 0 diberikan jika mahasiswa berasal dari Institut Pertanian Bogor, nilai 1 diberikan jika mahasiswa berasal dari Universitas Pakuan, dan nilai 2 diberikan jika mahasiswa berasal dari Universitas Juanda. Diperoleh nilai $p$ value sebesar 0.000, sehingga keputusan hipotesis yaitu tolak H0 karena $p$ value $<0.050$. Nilai original sample adalah 
sebesar 0.405 yang artinya variabel signifikan. Oleh karena variabel berpengaruh signifikan, dapat dikatakan bahwa mahasiswa yang berasal dari Universitas Juanda memiliki literasi keuangan syariah yang lebih baik dibandingkan mahasiswa yang berasal dari luar Universitas Juanda.

Hasil penelitian pada variabel IPK tidak sesuai dengan hipotesis yang telah ditetapkan. Menurut Fadhly (2019), semakin tinggi IPK mahasiswa maka literasi keuangan syariah akan semakin baik. Hal ini tidak sejalan dengan penelitian karena mahasiswa yang memiliki tingkat literasi keuangan yang baik rata-rata berada pada kisaran $2.00 \leq$ IPK $<2.75$. Menurut Krishna et al. (2010), tingkat literasi keuangan tidak ditentukan oleh kemampuan intelektual (yang dianalogikan dalam nilai IPK), tetapi lebih ditentukan oleh latar belakang pendidikan. Berdasarkan fakta dan data yang terjadi di lapangan bahwa hanya ada 5 dari 30 mahasiswa atau sebesar $16.7 \%$ dengan IPK pada range $\geq 3.51$ yang termasuk ke dalam kategori well literate.

Hasil penelitian pada variabel sumber informasi tidak sesuai dengan hipotesis yang telah ditetapkan. Menurut Ameliawati \& Setiyani (2018), terdapat pengaruh sumber informasi dari keluarga terhadap literasi keuangan syariah. Menurut Sohn et al. (2012), komunikasi keluarga terkait masalah konsumsi seiring bertambahnya usia akan menurun, sedangkan komunikasi dari teman sebaya terkait konsumsi akan meningkat seiring bertambahnya usia. Artinya, pengaruh orang tua tampaknya perlahan-lahan tumbuh semakin lemah dari waktu ke waktu. Sementara pengaruh teman sebaya tumbuh lebih kuat seiring bertambahnya usia. Sumber informasi dari media juga terbukti memiliki hubungan yang signifikan dengan keuangan. Meskipun keluarga dilaporkan menjadi sosialisasi yang paling penting, tetapi keluarga tidak berkontribusi signifikan terhadap peningkatan literasi keuangan mahasiswa.

Hasil penelitian pada variabel religiusitas tidak sesuai dengan hipotesis yang telah ditetapkan dan tidak sejalan dengan penelitian. Menurut Sohn et al. (2012), mahasiswa umumnya memiliki pengalaman langsung dalam penggunaan perbankan syariah. Hasil penelitian tersebut menunjukkan bahwa jenis pengalaman belajar langsung mungkin menjadi kunci untuk meningkatkan literasi keuangan. Berdasarkan fakta dan data yang terjadi di lapangan, mayoritas mahasiswa termasuk ke dalam golongan religius tetapi tingkat inklusi perbankan syariah mahasiswa rendah. Artinya, pengalaman dalam menggunakan perbankan syariah berpengaruh terhadap peningkatan literasi keuangan syariah mahasiswa.

\section{SIMPULAN}

Dalam penelitian disimpulkan bahwa rata-rata tingkat literasi keuangan mahasiswa di Bogor sebesar $50.2 \%$ dan tergolong sufficient literate. Karena masih rendahnya literasi mahasiswa, pemerintah mengeluarkan Peraturan Otoritas Jasa Keuangan 76/POJK07/2016 tentang peningkatan literasi dan inklusi keuangan di sektor jasa keuangan bagi konsumen/masyarakat yakni sebesar $75 \%$. Target tersebut sesuai dengan yang dicanangkan oleh pemerintah melalui Peraturan Presiden Republik Indonesia Nomor 82 tahun 2016 tentang Strategi Nasional Keuangan Inklusif (SNKI), pada akhir tahun 2019. Untuk meningkatkan literasi mahasiswa dari sufficient literate menjadi well literate, diharapkan pihak kampus ataupun organisasi mahasiswa dapat mengadakan seminar atau pelatihan terkait keuangan secara berkala untuk meningkatkan literasi keuangan mahasiswa dan dapat bekerja sama dengan lembaga formal seperti OJK atau otoritas lainnya. 


\section{DAFTAR PUSTAKA}

Abdullah, R. \& Razak, A. L. H. A. (2015). Exploratory research into financial literacy in Brunei Darussalam. Retrieved from http://www.researchgate.net/publication/283225608. doi:10.13140/RG. 2.1.4815.1765.

Adams, G. A. \& Rau, B. L. (2011). Putting off tomorrow to do what you want today: Planning for retirement. American Psychologist, 66(3), 180-192.

Akmal, H. \& Saputra, Y. E. (2016). Analisis tingkat literasi keuangan. JEBI (Jurnal Ekonomi dan Bisnis Islam), 1(2), 235-244.

Ameliawati, M. \& Setiyani, R. (2018). The influence of financial attitude, financial socialization, and financial experience to financial management behavior with financial literacy as the mediation variable. International Conference on Economics, Business and Economic Education 2018, KnE Social Sciences, 811-832.

[APJII] Asosiasi Penyelenggara Jasa Internet Indonesia. (2018). Penetrasi Pengguna Internet 2018 Berdasarkan Umur [Internet]. [diunduh 2020 Apr 8]. Tersedia pada: https://apjii.or.id.

Bentler, P. M. \& Chou, C. P. (1987). Practical issues in structural modeling. Sociological Methods and Research, 16(1), 78-117.

Boon, T. H., Yee, H. S. \& Ting, H. W. (2011). Financial literacy and personal financial planning in Klang Valley, Malaysia. International Journal of Economics and Management, 5(1), 149-168.

[BPS] Badan Pusat Statistik. Proyeksi Penduduk Menurut Provinsi 2020 [Internet]. [diunduh 2020 Jul 8]. Tersedia pada: http://www.bps.go.id.

Brigham, E. F. \& Houston, J. F. (2006). Dasar-dasar Manajemen Keuangan Buku 1 Ed ke-11. Jakarta (ID), Salemba Empat.

Carpena, F., Cole, S. A., Shapiro, J., \& Zia, B. (2011). Unpacking the causal chain of financial literacy. The World Bank (Policy Research Working Paper Series).

Chen, H. \& Volpe, R. P. (1998). An analysis of personal financial literacy among college students. Financial Services Review, 7(2),107-128.

Clark, R. L., d'Ambrosio, M. B., McDermed, A. A., \& Sawant, K. (2006). Retirement plans and saving decisions: The role of information and education. Journal of Pension Economics and Finance, 5(1), 45-67.

Dewantara, M. M. (2014). Pengetahuan, Nilai Religiusitas, Sikap dan Perilaku Membaca Label Halal pada Mahasiswa. (Skripsi, Institut Pertanian Bogor, Bogor, Indonesia).

Fadhly, F. A. (2019). Literasi Keuangan dan Faktor-Faktor yang Memengaruhi Literasi Keuangan Mahasiswa S1 Institut Pertanian Bogor. (Skripsi, Institut Pertanian Bogor, Bogor, Indonesia).

Ghozali, I. (2011). Aplikasi Analisis Multivariate Dengan Program SPSS. Semarang (ID), Badan Penerbit Universitas Diponegoro.

Ghozali, I. (2013). Aplikasi Analisis Multivariate dengan Program IBM SPSS 21 Update PLS Regresi. Semarang (ID), Badan Penerbit Universitas Diponegoro.

Ghozali I \& Latan, H. (2015). Partial Least Squares: Konsep, Teknik dan Aplikasi Menggunakan Program SmartPLS 3.0. Yogyakarta (ID), Badan Penerbit Undip.

Huston, S. J. (2010). Measuring financial literacy. Journal of Consumer Affairs, 44(2), 296-316.

Kasmir, S. E. (2010). Pengantar Manajemen Keuangan. Jakarta (ID), Kencana.

Keown, A. J., Martin, J. D., Petty, J. W., \& Scott, D. F. (2017). Manajemen Keuangan: Prinsip dan Penerapan. Jakarta (ID), PT Indeks.

Krishna, A., Rofaida, R. \& Sari, M. (2010). Analisis tingkat literasi keuangan di kalangan mahasiswa dan faktor-faktor yang mempengaruhinya (survey pada mahasiswa Universitas Pendidikan Indonesia). In Proceedings of the 4th International Conference on Teacher Education, 4(1), 552-560.

Lusardi, A, \& Mitchell, O. S. (2014). The economic importance of financial literacy: Theory and evidence. Journal of economic literature, 52(1), 5-44.

Margaretha, F. \& Pambudhi, R. A. (2015). Tingkat literasi keuangan pada mahasiswa S-1 fakultas ekonomi. Jurnal Manajemen dan Kewirausahaan, 17(1), 76-85.

Martono. (2004). Bank dan Lembaga Keuangan Lain. Yogyakarta (ID), Ekonisia. 
Moeljadi. (2006). Manajemen Keuangan Pendekatan Kuantitatif dan Kualitatif. Malang (ID), Bayumedia.

[OECD] Organization of Economic Co-Operation and Development. (2006). The Importance of Financial Education [Internet]. [diunduh 2019 Jan 19]. Tersedia pada: http://www.oecd.org.

[OECD] Organization of Economic Co-Operation and Development. (2017). G20/OECD INFE Report on Adult Financial Literacy in G20 countries [Internet]. [diunduh 2019 Des 19]. Tersedia pada: http://www.oecd.org/.

[OECD/INFE] Organization of Economic Co-Operation and Development/International Network on Financial Education. (2018). Measuring Financial Literacy: Core Questionnaire in Measuring Financial Literacy: Questionnaire and Guidance Notes for conducting an Internationally Comparable Survey of Financial Literacy. Paris: OECD.

[OJK] Otoritas Jasa Keuangan. (2016). Tingkat Literasi Keuangan Penduduk Indonesia [Internet]. [diunduh 2020 Jan 17]. Tersedia pada: http://www.ojk.go.id.

[OJK] Otoritas Jasa Keuangan. (2017). Strategi Nasional Literasi Keuangan Indonesia (Revisit 2017) [Internet]. [diunduh 2019 Des 5]. Tersedia pada: http://www.ojk.go.id.

[POSMI] Portal Resmi Kabupaten Bogor. (2020). Tingkatkan Gerakan Membaca di Kabupaten Bogor, 40 Bunda Literasi Kecamatan Dikukuhkan. [Internet]. [diakses 2020 Januari 17]. Tersedia pada: https://bogorkab.go.id/post/detail/tingkatkan-gerakan-membaca-di-kabupatenbogor-40-bunda-literasi-kecamatan-dikukuhkan.

Rahim, S. H. A., Rashid, R. A. \& Hamed, A. B. (2016). Islamic financial literacy and its determinants among university students: An exploratory factor analysis. International Journal of Economics and Financial Issues, 6(7S), 32-35.

Remund, D. L. (2010). Financial literacy explicated: The case for a clearer definition in an increasingly complex economy. Journal of Consumer Affairs, 44(2), 276-295.

Riduwan, M. B. A. (2010). Skala Pengukuran Variabel-Variabel Penelitian. Bandung (ID), Alfabeta.

Smith, D. \& Langfield-Smith, K. (2004). Structural equation modeling in management accounting research: Critical analysis and opportunities. Journal of accounting Literature, 23, 49-86.

Sohn, S. H., Joo, S. H., Grable, J. E., Lee, S., \& Kim, M. (2012). Adolescents' financial literacy: The role of financial socialization agents, financial experiences, and money attitudes in shaping financial literacy among South Korean youth. Journal of adolescence, 35(4), 969-980.

Sugiyono. (2013). Metode Penelitian Bisnis. Bandung (ID), Alfabeta.

Yamin, S. \& Kurniawan, H. (2011). Generasi Baru Mengolah Data dengan Partial Least Square Path Modeling. Jakarta (ID), Salemba Infotek. 